\title{
O Apostolado Positivista do Brasil e a ideia de "Ordem e Progresso" (1881-1894)
}

\author{
Carlos Roberto Lima Ribeiro*, Alvaro Gabriel Bianchi Mendez (orientador).
}

\section{Resumo}

O objetivo central deste projeto de pesquisa é analisar as Circulares Anuais do Apostolado Positivista do Brasil (18811894), e o documento "Bases de uma Constituição Política Ditatorial Federativa para a República Brasileira". A proposta é identificar e compreender o conceito de "ordem" relacionado a uma ideia de "progresso" construído e estabelecido pelo positivismo no Brasil.

\section{Palavras-chave:}

Positivismo, Ordem, Progresso

\section{Introdução}

A ideia de "ordem e progresso" remonta ao positivismo estabelecido por Augusto Comte. Fortemente impactado pela Revolução Francesa e por suas conseqüências, o filósofo francês construiu uma doutrina com o objetivo central de harmonizar a "ordem" com o "progresso". Identificado com a ordem existente no Antigo Regime, mas, também, reconhecendo a necessidade do progresso, reivindicado pela Revolução Francesa, Comte desenvolve uma doutrina na qual "ordem e progresso" fossem compatíveis e não mutuamente excludentes, como se pensava naquele momento. O positivismo seria, então, a doutrina capaz de regenerar a sociedade, harmonizando a ordem com o progresso, a fim de, evitar a ocorrência de revoluções.

O objetivo principal da pesquisa é analisar as Circulares Anuais do Apostolado Positivista do Brasil, referentes ao período de 1881-1894, e o documento "Bases de uma Constituição Política Ditatorial Federativa para a República Brasileira", publicado em 1890, também pelo Apostolado. A proposta é identificar e compreender a construção e o estabelecimento do conceito de "ordem e progresso", pelo positivismo no Brasil.

\section{Resultados e Discussão}

O Apostolado Positivista do Brasil, considerado o principal grupo positivista em ação no país no final do século XIX, adaptou a doutrina positivista e também o lema positivista "ordem e progresso", ao contexto da realidade brasileira. No momento inicial de sua atuação política, a principal bandeira defendida pelo Apostolado era a da "incorporação do proletariado na sociedade moderna", que se faria, inicialmente, pela abolição da escravidão, a principal demanda social que se colocava naquele momento. Defendia a abolição imediata da escravidão, inclusive expulsando um de seus membros que possuía escravos em sua propriedade rural. Esse tema era central, pois, na leitura que o Apostolado fazia da realidade brasileira, caso a "incorporação do proletariado" não ocorresse, haveria uma revolução socialista. O Apostolado buscava convencer 0 proletariado de que o positivismo tinha as melhores condições para realizar os seus anseios. O ponto culminante para a organização de uma sociedade positivista foi a implantação da República brasileira. Logo em seguida, em 1890, o Apostolado apresentou um projeto onde indicava quais deveriam ser as bases de uma Constituição para a República brasileira, e preconizava um governo Republicano Ditatorial Federativo, assistido por uma Assembléia Orçamentária. Paralelamente, a essas e outras questões, o Apostolado disputou 0 protagonismo pela representação do positivismo comteano. A partir de 1883, com o rompimento de relações com o dirigente máximo do positivismo francês e mundial, o Apostolado se autodenomina como o "verdadeiro" representante dessa corrente positivista, manifestando, inclusive, o interesse de constituir um escritório em Paris.

\section{Conclusões}

Espécie de fórmula, a ideia de "ordem e progresso" sintetiza o ideal positivista. A "ordem" significa a base, a estrutura, as instituições sociais, a própria estática social, enquanto que, o "progresso", representa a dinâmica social. Nesse sentido, o "progresso" seria um desenvolvimento da "ordem", ocorreria sem mudanças abruptas na organização social, sem revoluções. O Apostolado Positivista do Brasil em sua atuação política procurou estabelecer as bases de uma sociedade positivista brasileira, buscando harmonizar, principalmente, as "questões sociais", para que houvesse um desenvolvimento gradual, que evitasse a ocorrência de uma revolução socialista. Uma sociedade positivista não foi implantada no Brasil, entretanto, é possível pensar que haveria na ideologia positivista "alguma relação mais profunda entre a índole dessa doutrina e o conjunto de contraditórias condições que deram origem à vida nacional e que a impelem" (Costa, 1967, p.276), e que, "ainda continua presente, principalmente, como suporte de novas ideologias" (Bastos, 1965, p.18).

\section{Agradecimentos}

Agradeço a UNICAMP e ao CNPq, por financiarem a pesquisa, ao meu orientador prof. Alvaro Bianchi, ao PEPOL pela oportunidade de discussões relevantes, aos companheiros de curso, a Amanda Santos amiga de todas as horas, ao meu pai em memória, a minha família pelo apoio e a àqueles que com paciência me escutaram falar sobre a pesquisa.

Bastos, Tocary Assis. O positivismo e a realidade brasileira. Belo Horizonte: Revista Brasileira de Estudos Políticos, 1965.

Costa, João Cruz. Contribuição à história das ideias no Brasil. 2 edição. Rio de Janeiro: Civilização Brasileira, 1967. 